account for the outward dipping contacts and great thickness of granite indicated by the gravity survey.

This two-fold structural division is better seen in other non-orogenic igneous provinces. In the White Mountains of New Hampshire, ring-dyke complexes composed of syenite, monzonite, and hastingsite- and riebeckite-granite are invaded and partly obliterated by massive plutons of the Conway biotite-granite which are structurally independent of the ring centres (Billings, 1955). Similarly in the Permo-Carboniferous igneous province of the Georgetown Inlier, north Queensland, large cauldron subsidence areas containing rhyodacite welded tuffs and associated granitic ring-complexes are engulfed by widespread intrusions of biotite-adamellite-the Elizabeth Creek granitewhich are rarely controlled by the earlier pattern of ring faulting (Branch, 1966).

It is interesting to consider the petrogenetic implications for the Nigerian province. The early cylindrical ring-complex structures, together with the volcanic piles which they invade, were formed by fairly small volumes of magma, for screens of country rocks are common between successive intrusions. This magma, highly differentiated from the earliest stage-the granites are varied and the volcanic rocks have a similar range of composition, including peralkaline types-may be the product of limited fractional melting within the crust. Bailey \& Schairer (1966) have suggested that this process would be capable of producing peralkaline magma and Bowden (personal communication and MS, 1968) has shown that some geochemical features of the Nigerian granites indicate an origin by partial melting of crustal rocks. The massive late intrusions of biotite-granite, with a slight excess of alumina over alkalis, may represent a more complete melting of basement rocks, the larger volumes of magma allowing their emplacement to be independent of the structural controls followed by the earlier ring-intrusions.

\title{
REFERENCES
}

AJAKAIYE, D. E. 1968. A gravity interpretation of the Liruei Younger Granite ring complex of Northern Nigeria. Geol. Mag., 105, 256-263.

BAILEY, D. K. \& SCHAIRER, J. F. 1966. The system $\mathrm{Na}_{2} \mathrm{O}-\mathrm{Al}_{2} \mathrm{O}_{3}-\mathrm{Fe}_{2} \mathrm{O}_{3}-\mathrm{SiO}_{2}$ at 1 atmosphere, and the petrogenesis of alkaline rocks. J. Petrology, 7, 114-170.

BILLINGS, M. P. 1955. Geologic Map of New Hampshire. Scale 1:250,000 (U.S. Geological Survey).

BRANCH, C. D. 1966. Volcanic cauldrons, ring complexes, and associated granites of the Georgetown Inlier, Queensland. Bull. Bur. Miner. Resour. Geol. Geophys. Aust., No.76.

TURNER, D. C. 1963. Ring-structures in the Sara-Fier Younger Granite complex, Northern Nigeria. Q. Jl geol. Soc. Lond., 119, 345-361.

\author{
INSTITUTE OF GEOLOGICAL SCIENCES, \\ EXHIBITION ROAD, \\ LONDON, S.W.7. \\ 21st October, 1968.
}

\section{MICROFOSSILS FROM THE CLEAVED SKIDDAW SLATES OF MURTON PIKE AND BROWNBER (CROSS FELL INLIER)}

SIR,-Following on from the preliminary investigations of Wadge, Owens \& Downie (1967), one of the present authors (T.R.L.) has undertaken a palynological investigation of all the main outcrops of the Skiddaw Slates in the Cross Fell Inlier. This has been done in conjunction with the resurvey of the area by Messrs. A. J. Wadge and I. C. Burgess and an attempt has been made to establish a working stratigraphic succession to facilitate the geological mapping.

Microfossils (acritarchs and chitinozoa), hitherto recorded only from the Milburn and Ellergill Beds (referred on graptolite evidence to the $D$. bifidus Zone of the Llanvirn), 
have now been recovered from the highly deformed rocks outcropping on Murton Pike and Brownber, and from the undated Skiddaw Slates in the northern part of the inlier (around Hungrigg Sike, Caterpallot and Melmerby Beck).

The recovery of microfossils from the Murton Pike and Brownber Slates is of especial interest since these rocks are affected by a well-developed slaty cleavage (S1), which is further refolded. A penetrative lineation (S2) accompanies the second (F2) folds, particularly well seen on Brownber (see Burgess 1966).

With the exception of Shotton's (1935) reference to a specimen of Glyptograptus from the Murton Pike Slates "unfortunately lost", no fossils have previously been recorded from the Skiddaw Slates of Murton Pike and Brownber. Elles (in Shotton) regarded the Glyptograptus as an advanced type, from which it was inferred that the Murton Pike Slates were not necessarily some of the oldest rocks in the area, in spite of their highly deformed state.

Several hundred microfossils have been recovered from the Murton Pike and Brownber Slates. These fossils are carbonised and frequently fragmentary, but permit tentative age assessment of the beds.

The following significant species have been identified from the beds exposed on Murton Pike and Brownber.

\section{Acritarchs}

Archaeohystrichosphaeridium cf. arenigum Timofeev (in Downie \& Ford 1966)

A. dentatum Timofeev

A. cf. dentatum Timofeev (in Downie \& Ford 1966)

A. cf. imperfectum Timofeev (in Downie \& Ford 1966)

A. pungens Timofeev

Baltisphaeridium aff. breviciliatum (Staplin) Martin (in Martin 1967)

B. cf. cristatum Downie (in Downie \& Ford 1966)

$B$. hirsutoides var. hamatum Downie

B. striatulum Vavrdova

? Priscogalea furcata Deunff

P. cf. simplex Deunff

Veryhachium lairdi (Deflandre) Deunff

V. sartbernardense Martin

$V$. valiente Cramer

Acanthodiacrodium lineata Deunff

? A. sukatschewi Timofeev

Lophodiacrodium sp.

\section{Chitinozoa}

? Conochitina chydaea Jenkins

C. oelandica Eisenack

? Cyathochitina calix Eisenack

Lagenochitina ovoidea Benoit \& Taugourdeau

$A$. cf. arenigum, $A$. cf. dentatum, $A$. cf. imperfectum and $B$. cf. cristatum were recorded by Downie \& Ford (1966) from the Lonan Flags of the Manx Slate sequence, for which they suggested a high Tremadocian or lower Arenig age. A. dentatum is recorded from the Glauconite Beds, and $A$. pungens and $A$. sukatschewi from the 
Tremadocian, of the Leningrad area (Timofeev 1959). Three other species, Priscogalea furcata, $P$. simplex and Acanthodiacrodium lineata, are known from the Tremadocian of the Sahara (Deunff 1961) and Baltisphaeridium striatulum is known from the Klabava Shales (Arenig) of Bohemia (Vavrdova 1966).

Set against this $B$. aff. breviciliatum, Veryhachuim lairdi, $V$. sartbernardense and $V$. valiente are all common in the bifidus-Llandeilo Shales of Sart-Bernard, Belgium (Martin 1966), but so far have not been recorded from pre-Llanvirn horizons. Thus an early Llanvirn or late Arenig age is possibly indicated.

This impression is confirmed when the microflora is compared with assemblages recovered from other parts of the Skiddaw Group in the Cross Fell Inlier. The assemblages from the Skiddaw Slates in the northern part of the inlier are clearly older and definitely Arenig. They are characterised by abundant species of Archaeohystrichosphaeridium Timofeev associated with diacromorph acritarchs. The Murton Pike and Brownber assemblages yielded far fewer species of Archaeohystrichosphaeridium and diacromorph acritarchs were extremely rare. However the Murton Pike and Brownber assemblages appear older than those from the Ellergill Beds. Llanvirnian species are present in the Ellergill Beds including $B$. aff. breviciliatum, $V$. lairdi, $V$. sartbernardense and $V$. valiente, but none of the 'earlier' forms including $A$. $c f$. imperfectum, $A$. cf. dentatum, $A$. pungens, Priscogalea furcata, $P$. simplex, Acanthodiacrodium lineata and $A$. sukatschewi was found. Moreover, only three of these seven species, $P$. furcata, $P$. simplex and $A$. sukatschewi have been seen in the Milburn Beds (D. bifidus Zone), so that an age older than the Milburn Beds may be indicated.

In the final assessment a late Arenig age appears most likely for the Murton Pike and Brownber slates although an early bifidus age cannot be excluded.

In the Cross Fell sequence, a stratigraphic position between the rocks in the northern part of the inlier and the Milburn Beds is suggested.

Palaeontologically there is no evidence for any major break in the Skiddaw Slate sequence of the Cross Fell Inlier, since there is a gradation from the oldest type of assemblages from the Hungrigg Sike area through to the youngest type of assemblages (from the Ellergill Beds).

The structural implications arising from this appear to be that the deformation in the Skiddaw Slates post-dates the youngest part of the Skiddaw Slate sequence (the Ellergill Beds) and that the Skiddaw Slates represent a group of strata which has responded differentially to tectonic pressure, and consequently displays marked contrasts in tectonic style.

It is intended to make the full results of this investigation available in a forthcoming publication.

\section{REFERENCES}

BURGESS, I. C. 1966. In Annual Report Inst. Geol. Sci. for 1965, Pt.1, p.55. Her Majesty's Stationery Office, London.

DEUNFF, J. 1961. Un microplankton à hystrichosphères dans le Trémadoc du Sahara. Rev. micropal., 4, 37-52.

DOWNIE, C. \& FORD, T. D. 1966. Microfossils from the Manx Slate Series. Proc. Yorks. geol. Soc., 35, 301-19.

MARTIN, F. 1966. Les acritarches de Sart-Bernard (Ordovicien Belge). Bull. Soc. belge géol., 74, 1-22.

SHOTTON, F. W. 1935. The stratigraphy and tectonics of the Cross Fell Inlier. Q. $J l$ geol. Soc. Lond., 91, 639-704.

TIMOFEEV, B. V. 1959. The ancient Baltic flora and its stratigraphic significance. V.N.I.G.R.I., Leningrad, Mem. 129,136 p., 25 pl.

VAVRDOVA, M. 1966. Palaeozoic microplankton from Central Bohemia. Geol. ustav CSA V, Prague.

WADGE, A. J., OWENS, B. \& DOWNIE, C. 1967. Microfossils from the Skiddaw Group. Geol. Mag., 104, 506-507.

INSTITUTE OF GEOLOGICAL SCIENCES,

T. R. LISTER,

I. C. BURGESS,

LEEDS.

4th November, 1968. 